International Journal of Legal Information 48.3, 2020, pp. 105-109. (C) The Author(s), 2021. Published by International Association of Law Libraries

doi:10.1017/jli.2020.28

\title{
In Memoriam: Three Tributes to Dan Wade ${ }^{1}$
}

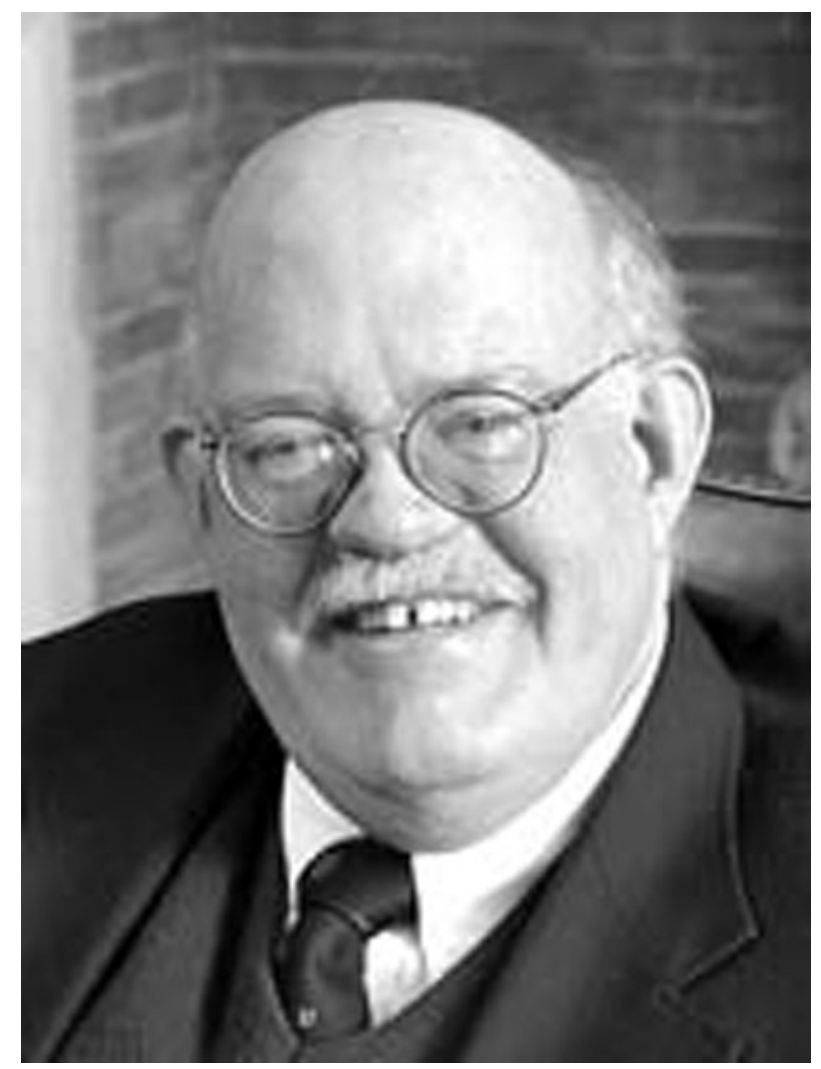

Daniel Lawrence Wade, 1944-2020

MARY RUMSEY ${ }^{2}$

Daniel (Dan) Wade, a pillar of the foreign and international law library world, died in May after a long illness. Dan worked for more than 40 years at Yale University. Most recently, Dan served as the Curator of the Foreign and International Law Collection at Yale's Lillian Goldman Law Library. Before that, he was an Associate Law Librarian for many years, specializing in foreign and international legal materials.

${ }^{1}$ This memorial actually comprises three separately-authored tributes to our friend and colleague, Dan Wade. The editor organized them into one single article-length piece because they are so closely linked in subject matter, tone, and intention.

2 (C) Mary Rumsey 2020. The author is Reference and Instructional Services Librarian at Willamette University College of Law. J.W. Long Law Library, in Salem, Oregon. 
An Indiana native, Dan received a B.A. degree in History from Manchester University in North Manchester, Indiana; an M.A. degree in Medieval Islamic History from Indiana University; an M.Div. from Bethany Theological Seminary; an M.A. in History of Religions from University of Chicago; a Juris Doctor from DePaul University; and an M.S. degree in Library and Informational Science from the University of Illinois. Although he eventually stopped accumulating more degrees, he maintained a lifelong love of reading and learning.

Before taking up his position at Yale, Dan also worked at Vanderbilt Law School and the University of Houston. At Vanderbilt, he worked with Adolf Sprudzs, one of several Europeans who became distinguished law librarians in the United States. Like those librarians, Dan read several languages.

In 1985, Dan helped found the Foreign, Comparative, and International Special Interest Section of the American Association for Law Libraries (AALL). Dan never wavered in his commitment to the organization. He edited newsletters, chaired the Section and countless committees, and spearheaded or helped lead numerous initiatives, including the Northeast Foreign Law Librarians Cooperative Group (NEFLLCG) and the FCIL-SIS Book Discussion Group. One of his major contributions to foreign and international librarianship consists of his efforts to train and nurture the next generations of FCIL librarians, through his writing, his work within AALL, and his mentoring.

Although Dan worked hard, his world was much larger than the law library. Dan's spirituality played a large role in his life. He belonged to the United Church of Christ and the Unitarian Society of Greater New Haven. Committed to social justice, he participated in many groups advancing human rights. Most of all, Dan treasured his family; his wife Carol, his two daughters, Alyson and Malory, son-in-law Darren, and his two grandsons, Luke and Emerson.

In July 2020, over 50 FCIL librarians memorialized Dan in a special issue of the FCIL-SIS Newsletter, ${ }^{3}$ which dubbed him an "FCIL Giant." Although each entry highlighted different memories, many of the writers described their first meeting with Dan in similar terms: I was new, I was intimidated, Dan welcomed me, and Dan encouraged or even mentored me.

My own experience with Dan Wade followed that pattern. I first encountered him in 2002, at the annual meeting of the International Association of Law Libraries (IALL). I was a new FCIL librarian from the University of Minnesota. Dan and I ended up in line together at a United Nations tour. I took a look at his Yale baseball cap and thought to myself, with some flyover-country defensiveness, "oh great, this guy's probably an East Coast snob." I made some inane remark about the country flags and how the breakup of the former Yugoslavia was probably good for the flag design industry. Suddenly we were engaged in a fascinating discussion of that breakup and its geopolitical effects. Dan knew a lot but also listened to what I had to say. From that day, I was a proud member of the Dan Wade Fan Club. We became friends, and I was honored that he and Carol made time for dinner with my husband and me when they visited Minneapolis a few years ago.

I worked with Dan on numerous FCIL-SIS committees. Dan's energy and perseverance, particularly related to the development of new FCIL librarians, always carried people along with him. I was happy that I could work with others to create the Daniel L. Wade Outstanding Service award, and make him the first recipient in 2006. As far as I'm concerned, Dan is not just an FCIL Giant; he is our FCIL Patron Saint.

\section{Dan Wade: An Appreciation Jennifer Allison 4}

I missed my original deadline to submit this piece. I was selected, along with Marylin Raisch and Mary Rumsey, ${ }^{5}$ to write this tribute to Dan shortly after we all learned that he had passed away on May $28,2020.6$

\footnotetext{
${ }^{3}$ Special Issue: "Remembering an FCIL Giant," FCIL-Newsletter (July 2020), https://www.aallnet.org/fcilsis/wp-content/ uploads/sites/7/2020/07/FCIL_-July-2020_Special-Issue.pdf.

${ }^{4}$ (C) Jennifer Allison 2020. The author is Librarian for Foreign, Comparative, and International Law, Harvard Law School Library, Cambridge, MA.

${ }^{5}$ One of the reasons I agreed to write a piece for this project, in addition to the great esteem I feel for Dan, was because I was so honored to be included in a group with Marylin and Mary, two of my mentors in FCIL librarianship.

${ }^{6}$ Obituary of Daniel Lawrence Wade, New HAVEn RegisTeR, Jun. 5, 2020, https://www.legacy.com/obituaries/nhregister/ obituary.aspx?n=daniel-lawrence-wade\&pid=196302951\&fhid=12030 [hereinafter Daniel Wade Obituary].
} 
Little did I know, when I agreed to do this, that I would spend that summer preparing for the strangest launch to an academic year in my entire 13-year career as a law librarian.

It was a summer without a vacation, because with the COVID-19 lockdown ${ }^{7}$ there was really no place to go that felt safe or relaxing, and in any event there was just too much to do regarding work. While I sat in my home office, planning for the fall, I was just hoping that I would somehow make it through and actually be able to teach our LL.M. students how to research and help them get the resources they needed to write their LL.M. theses, given that those students would be dialed in from their homes all over the globe, and that our print collection in the law library would be locked away an indeterminate time in the future.

During that summer, I wrote this piece in my head at least 50 times, but could not muster the time or energy to commit it to the screen. Now, as I write it, we have just completed week two of the Fall 2020 semester. During the past week, I have spent what feels like approximately 5,752 hours on Zoom, an online conferencing tool that most of us had never heard of before February of this year. The deadline has passed with nothing written, so I figured I'd better get going.

To get myself in the correct frame of mind to write about Dan, I did what Dan was always telling us we should do: I put down my phone and opened a book. ${ }^{8}$ I am currently reading The Eighth Life, a 934-page epic first published in German in 2014 by the Georgian author Nino Haratischvili. ${ }^{9}$ Although I read German well enough to have tackled it in the original, I lack the will at the moment, so I have been plodding my way through the recently-published English translation throughout this entire strange summer, wishing I had more time and energy to commit to it because I really like the story, a multi-generational saga of a family from the country of Georgia spanning the entire 20th century. The characters are scattered throughout Europe (from Tblisi to Moscow to Prague to London) and trying to make sense of the world and their place in it. I am not $100 \%$ sure how Dan felt about modern novels like this; I imagine his tastes ran more to classical literature and to nonfiction. Perhaps he would have enjoyed it.

Anyway, I am currently at the point in the story describing the birth of one of the characters, which took place in Moscow in 1970. It includes the most extraordinary paragraph describing the state of the world at that time:

She was born during President Nixon's first term in office, one year after Neil Armstrong's landing on the moon, two years after Gagarin was killed in a mysterious plane crash, one year before Bernd Sievert was shot forty-three times and seriously wounded by East German border guards while attempting to escape over the Berlin Wall. The same year the Beatles announced they were splitting up, unleashing a flood of tears all around the world. Shortly before the Easy Rider wave washed over the eastern half of the globe and had every twenty-year-old praying that some blessed person would smuggle Harleys across every border. Shortly before Idi Amin seized power in Uganda; during the protest by the dissident Sakharov against sending members of the opposition to Soviet mental hospitals; and some months after the Nobel Prize was awarded to a certain Mr. Beckett, who was still unknown in the East and, of course, nonetheless or perhaps for that very reason - banned. Two years after the revolution that started in Paris - people didn't know whether the history books would record it as failed or successful, or whether it could even be described as a revolution. Shortly after the publication of an article in LIFE magazine about the My Lai massacre in Vietnam, in which the American Task Force Barker unit raped, murdered, and wiped out an entire village. ${ }^{10}$

${ }^{7}$ At the end of 2019, the emergence of COVID-19, a virus that can cause severe respiratory disease leading to death, caused a global pandemic. A massive institutional shutdown was implemented around the world, forcing people to work from home. As of this writing (September 12, 2020), many institutions are still under this lockdown, and there have been over 6.4 million COVID-19 cases (and nearly 200,000 deaths) in the United States alone. See Covid in the U.S.: Latest Map and Case Count, N. Y. TIMES (updated Sept. 12, 2020), https://www.nytimes.com/interactive/2020/us/coronavirus-us-cases.html [https://perma.cc/ 4KLY-DFAL].

${ }^{8}$ As I wrote in my short tribute to Dan for the FCIL-SIS newsletter, "Dan was always gently reminding us that we should read more. ... These days, whenever I decide to read a book instead of looking at my phone or watching TV, I do so with Dan in mind." Jennifer Allison, Tribute to Dan Wade, FCIL Newsletter: Remembering DAn Wade - The FCIL Giant 4 (July 2020 ) (special issue), https:/www.aallnet.org/fcilsis/wp-content/uploads/sites/7/2020/07/FCIL_-July-2020_Special-Issue.pdf.

${ }^{9}$ Nino Haratischvili, The Eighth Life (For Brilka) (Charlotte Collins \& Ruth Martin trans., 2019).

${ }^{10}$ Id. at $486-87$. 
While I hate that that quote ends the way it does, I include it here for a very specific reason. Dan was born on March 6, 1944, which means that he turned 26 years old in $1970 .{ }^{11} \mathrm{I}$ am not exactly sure where he was on his educational journey at this point in time: over the course of his life, Dan, extraordinarily, earned a B.A., a master's degree in divinity, two master's degrees in history, an M.L.I.S., and a J.D. ${ }^{12}$ However, knowing Dan, I imagine he was extremely well-read in current affairs even as a 26-year-old student, and could have had a long and thoughtful conversation about each of the events listed in this quote.

The beautiful thing about Dan was that, if you were to have had those conversations with him about events that happened before you were born (as would be the case in this situation, as I was born in 1971), he never made you feel small for what you didn't know. Dan's manner was that of a generous mentor and a gracious friend, and that came through in every conversation I ever had with him. He was never one to lord over others, even though he did know more on nearly every topic than most people you will ever meet.

I had the tremendous good fortune to have visited Dan and his colleagues several times at Yale. I had never been there before I took my current job at Harvard at the end of 2012. When I first arrived in Cambridge to start working at Harvard, having lived my entire life on the West Coast and firmly in awe of the mystique of the Ivy League, my imposter syndrome was off the charts. I basically spent my first few years there wondering why on earth they had hired me, an upstart from California.

I can honestly say that the time I spent with Dan in New Haven was critical in helping me overcome my belief that I didn't belong in the world I now found myself. Dan treated me like a peer, an equal, even though I clearly was not. He deeply respected Harvard, and never seemed to bother with the silly rivalry that has persisted between the two institutions. He seemed glad for me that I had landed there, and he knew that I would benefit from its extraordinary collection of foreign and international legal materials and from the mentorship of my colleagues there. ${ }^{13}$

He also made a point of telling me about his own journey as a law librarian, which included working at the law libraries at the University of Houston and Vanderbilt before coming to Yale. I was shocked, because in my mind there were few people who personified the prestige and intellectual greatness of the Ivy League in general, and Yale specifically, more than Dan did. I had always just assumed that he had been at Yale his whole career, maybe even his whole life.

Dan always suggested that we take a walk around campus together when I was there for a visit, even if it was a day that he was obviously not at $100 \%$ physically. I always tried to beg off, not wanting him to exert himself unnecessarily for my benefit, but he insisted. One thing that struck me every time we went on one of these walks was how warmly everyone greeted him: he was clearly a well-known and beloved figure wherever he went on the Yale campus, including the beautiful Sterling Memorial Library and the wonderous Beinecke Rare Book \& Manuscript Library. I am so glad I saw those places with him, and that he was able to tell me about them.

During one of my visits, Dan asked me if I was considering applying for the FCIL librarian position that was open at Yale at the time. He told me how wonderful he thought it would be to work with me as a colleague. I nearly wept in gratitude when I heard that. Personal circumstances prevented me from applying for the job: I was preparing to take a one-year leave of absence from Harvard to go to Germany to pursue an LL.M. in German law at the time. However, I will never forget how it felt to know that Dan valued me enough to ask me if I would consider joining their library.

How Dan lived is a lesson for all of us: generous of heart and spirit, with a commitment to being well-read, contemplative, curious, and kind. He faced challenges with bravery and grace, and chose not to complain, but to live as fully as he was able to do. He cared deeply about people, especially those in the generations that came after him, ${ }^{14}$ and wanted them to succeed. He loved his family, and never failed to remind us that it was because of Carol, his

${ }^{11}$ Daniel Wade Obituary, supra note 2.

12 Id.

13 Of my colleagues at the Harvard Law Library, he especially admired Bridget Reischer, our Collection Development Librarian for Foreign and International Law. Bridget retired from Harvard on July 31, 2020 after nearly 30 years of service, an occasion which made this strange and forlorn summer seem even more so.

${ }^{14}$ When asked about his most significant professional achievement, Dan replied that it "has been in the training of the next generation of foreign and international law librarians, because they can help others." FCIL-SIS, Introducing...Daniel Wade as the September FCIL Librarian of the Month, DipLawMatic Dialogues (Aug. 29, 2014), https://fcilsis.wordpress.com/2014/08/ 29/introducingdaniel-wade-as-the-september-fcil-librarian-of-the-month/. 
"indulgent wife," that he had been able to achieve all of his academic accomplishments. ${ }^{15}$ Those of us who knew him will miss him, but we, and our beloved profession of foreign and international law librarianship, are better because of his influence, his generosity, and his care.

\section{Tribute to Daniel L. Wade MARYlin J. RAISCH ${ }^{16}$}

Over the many years that I attended conferences with our beloved colleague Dan Wade, I observed his kindness and his intellectual curiosity in many different contexts. For this reason I have been able to write about Dan after his passing in May for more than one organization to which we both belonged, and I have not had to recycle or repeat my memories! What bears repeating are his professional accomplishments and tireless promotion of foreign and international law librarianship and study.

Dan was a champion of human rights and civil rights, and he did this with the integrity of the now-familiar phrase "walking the talk." He and his family lived with diversity in their community and modesty in support of the welfare of all. But as Yale's Curator of the Foreign and International Law Collection at the Lillian Goldman Law Library, Dan was living large in the best intellectual sense. He founded the newsletter of the Foreign, International, and Comparative Law Special Interest Section (FCIL) of the American Association of Law Libraries (AALL), and then decades later a human rights book club. (Please see the special issue of the newsletter, "Remembering Dan Wade" dedicated to Dan with more tributes from colleagues, including myself, linked for public viewing).

Dan saw the larger picture, and it is fitting to celebrate him in the context of the Annual Courses of IALL because of his broad engagement with law and culture. Among his many academic degrees is an M.A. in the History of Religions from the University of Chicago. When I met Dan at Yale and later in meetings at the summer conference of the American Association of Law Libraries, I felt I'd found a kindred spirit in his broad interest in languages, history, and religion. He showed how that interdisciplinary outreach helped him curate meaningful materials to train lawyers as humanists in a time when the "rational actor" replaced the wonderful "man on the Clapham omnibus" as the reasonable person in torts (law and economics). He respected the empirical but defended the impractical. He embraced the study of Latin American and African law and tracked minority languages as well as massive projects to cover these jurisdictions in American law libraries. I encourage members of IALL to honor Dan with continuing emphasis on the annual course since Dan was all about learning more and knowing the subject matter; what's inside the books as well as how to manage them and acquire them.

Dan had a terrific sense of humor and was far from the introverted scholar; he was the greeter out front in his Yale domain where a charmingly odd wooden rabbit guarded the staircase at one point. During a workshop on international trade law, one of the many for training future FCIL librarians, Dan was in front of us in his usual suit, a professional but appropriately rumpled and professorial figure. This was before cell phones/smartphones, so he had brought a record player quietly to the desk. At the end of the talk Dan suddenly removed his jacket, tie and shirt to reveal a T-shirt, all to the beat of a Latin mariachi band, celebrating ... NAFTA and Mexico. He loved a visual joke, and was, for all his serious questions and sometimes earnest causes and projects, perfectly capable of being the anti-librarian, the disrupter. He was also the mentor and the friend of all newer librarians, starting an award at AALL for the newest one each year. It was real: a bottle of wine, usually. We continue the tradition to this day at our FCIL business meeting.

This was Dan as I knew him: a serious celebrant of life and law. We miss you, dear friend and colleague. Thank you for being an inspiring leader and sincere friend.

${ }^{15}$ Teresa Stanton, Oral History: Dan Wade, FCIL-SIS OrAL Histories, https://www.aallnet.org/fcilsis/about-us/history/ oral-histories/dan-wade/.

16 C Marylin Raisch 2020. The author is Associate Director for Research \& Collection Development, Georgetown Law Center, Georgetown Law Library, Georgetown Law Center, Washington, D.C. 